\title{
Natural focal infections as one of the risk factors for the agricultural workers health
}

\author{
Anton Martsev ${ }^{1, *}$ \\ ${ }^{1}$ Vladimir State University named after A.G. and N.G. Stoletovs', Gorky Street 87, 600000, Vladimir, \\ Russia
}

\begin{abstract}
The research deals with the assessment of the epidemiological and epizootic situation in the Vladimir region, concerning natural focal infections in the context of agricultural activities. The retrospective analysis of statistical data on morbidity anthropozoonoses taken from the Report forms №2 "Information on infectious and parasitic diseases" FBUZ "Hygiene and Epidemiology Center in Vladimir region" of Rospotrebnadzor Department of the Vladimir region during the period of 1958 - 2016. The study of the biological material in respect of pathogen the natural focal infections were conducted in the laboratory of naturalfocal and especially dangerous infections FBUZ "Hygiene and Epidemiology Center in Vladimir region" Rospotrebnadzor Department of the Vladimir region. The following natural-focal diseases have been stated to be registered as important in the context of agriculture in the Vladimir region: hemorrhagic fever with renal syndrome (HFRS), leptospirosis and tularemia. HFRS domonates in the morbidity structure. Annual laboratory tests of the biological material regarding the pathogens of natural focal infections indicate the presence of epizootics among mouse-like rodents, red vole (M. glareolus) being the dominant species among them. The ratio of HFRS male to female is approximately 3 to 1 Positive results of the laboratory studies indicate epizootic activity and constant risk of exacerbation of the epidemic situation regarding zooanthroponotic infections, and zero human morbidity during a number of years does not speak of the attenuation of the natural infection focus and the basis for stopping the preventive measures.
\end{abstract}

\section{Introduction}

In terms of the increased farming intensification in Russia, related to the import substitution strategy, the issues of pathogens monitoring of natural infections foci as the risk factors for the farmers health involved in agro-industrial sector are becoming very relevant. In this regard, the research objective was to assess the epidemic-epizootic situation in the Vladimir region dealing with the complex of natural focal infections in the context of agricultural activities.

\footnotetext{
* Corresponding author: martsevaa@yandex.ru
} 


\section{Materials and methods}

The study presents the retrospective statistics analysis concerning population morbidity by zooantroponoses received from the report form №2 "infectious and parasitic diseases data" FBUZ "Hygiene and Epidemiology Center in Vladimir region" Rospotrebnadzor Department of the Vladimir region during the period of 1958 - 2016. Biological material testing regarding pathogens of natural focal infections was carried out in the laboratory of natural focal and especially dangerous infections of FBUZ "Hygiene and Epidemiology Center in Vladimir region" Rospotrebnadzor Department of the Vladimir region (HEC).

\section{Results}

Natural conditions of the Vladimir region determine the possibility of pathogens circulation of a number of natural focal infections [1-4]. According to the official data, the region area is endemic for the following natural focal infectious diseases: hemorrhagic fever with renal syndrome (HFRS), leptospirosis and tularemia (fig. 1).

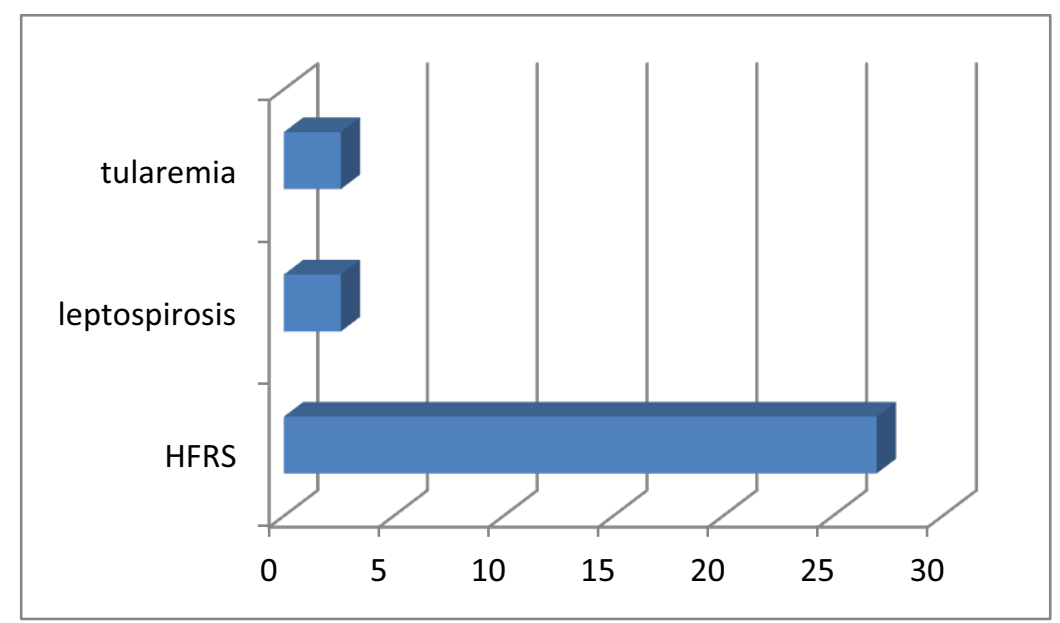

Fig. 1. Natural focal infectious diseases in Vladimir region in 2016 year.

\section{Discussion}

In recent decades the natural foci of a number of zoonoses, in particular hemorrhagic fever with renal syndrome (HFRS) have been activated. This viral non-transmissive zoonosis in Russia is leading among zoonotic viral infections and takes almost the first place among all natural human focal diseases. During several years the number of the registered cases reaches 20,000 and more [5,6]. Rodents are HFRS infection source, and the virus does not have a pronounced monohostality, so many local rodent fauna can become dangerous. The problem of human susceptibility against the causative agents of HFRS remained unsolved. It is assumed that a sufficiently large dose is required for being infected. Many people living within the natural foci, but for a few exceptions, do not get infected with HFRS. Apparently, even in childhood, local residents probably gradually get infected for the first time with not very large doses, are exposed to epidemic. The material from 367 small mammals (rodents) was serologically examined during the period of $2013-2015$, in order to diagnose the epizootic process in the region, 15 of them gave positive result. The red vole (M. glareolus) is the dominant species among the Gero mouse-like rodents that fall 
into the crushers. Additionally the following rodents are found among the caught rodents (in descending order): small forest mouse (A. uralensis), grey vole (Microtus), water vole (A. amphibius), field mouse (A. agrarius) and brown vole (Sorex). Insufficient differentiated diagnostics does not allow judging the pathogen type (Puumala, Dobrova or others) and, consequently, the main pathogen reservoir in nature remains unknown. It is worth noting that the number of HFRS cases tends to increase in the region.

During the considered period (1978 - 2016), 354 cases were registered, which increased from 1 case in 1978 up to 31 in 2016. Most frequently the incidence is registered in Gorokhovets, Kameshkovo and Selivanovo districts. For the entire analyzed period, a single case was registered in the Alexandrovo district (fig. 2).

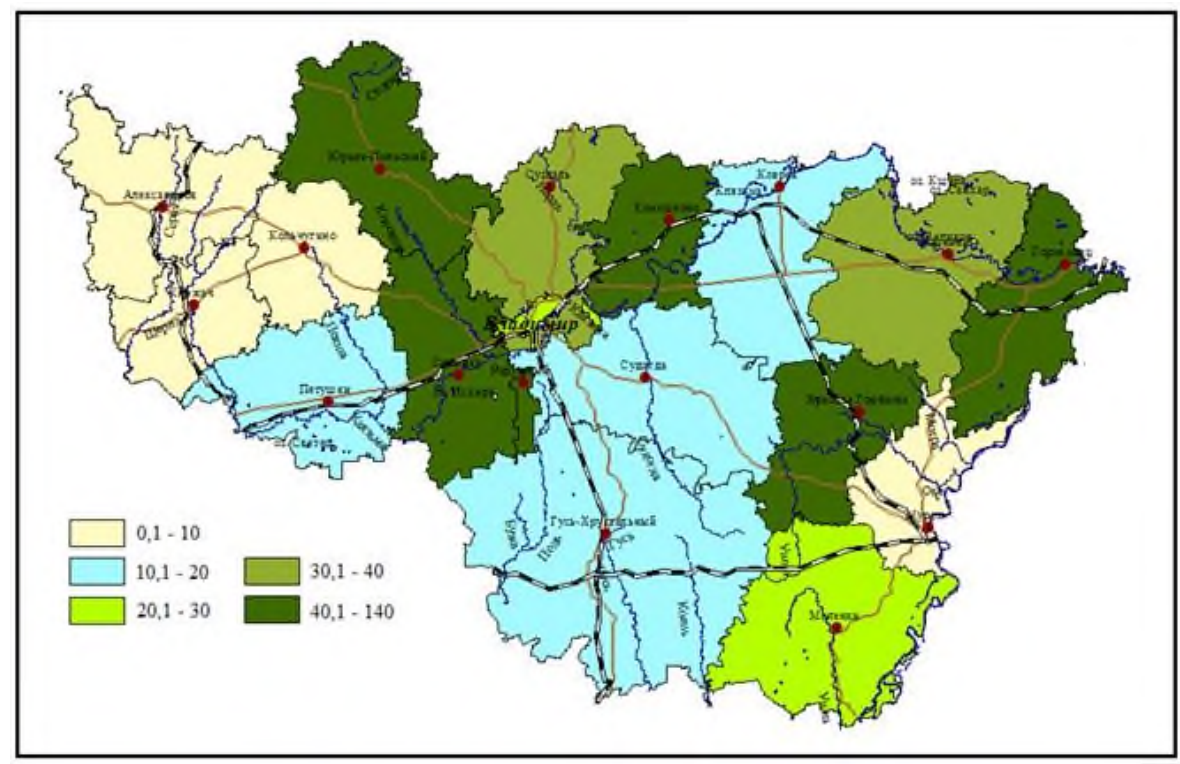

Fig. 2. Long term HFRS incidence in the Vladimir region (number of patients per 100,000 population).

The analysis of the infection reasons and conditions indicates that the main risk factors of the infection transmission are harvesting in the fields and in suburban areas during haymaking, as well as visiting forest areas, in some cases - fishing. Basically people get infected through the air and dust (two-thirds of all cases). The ratio of the sick male and female is approximately 3 to 1 ; the number of urban and rural residents is almost equal.

Leptospirosis is one of the most common zoonotic diseases, registered in more than 80 countries, including Russia [7]. Infection reservoirs in nature are various animals living in different climatogeographic zones. Most areas of Russia are characterized with the pronounced and steady trend towards leptospirosis incidence increase among humans. The epidemic activity of leptospirosis foci in residential areas, including large cities has been increasing. In 2005-2007 about 600-800 leptospirosis cases were registered annually, mainly in the Southern, Central and North-Western Federal districts, where the incidence ranged from 0.3 to 1.2 cases per 100 thousand people annually with $3.3 \%$ average mortality rate [8]. The high infection prevalence is stipulated by the peculiarities of natural and climatic conditions causing the formation and long-term existence of natural leptospirosis focus. The incidence dynamics is cyclical, and we can assume that the longer is the remission, the more serious is the subsequent outbreak. Most frequently leptospirosis incidence is registered among the residents of the North-East areas of the region (Vyazniky 
and Gorokhovets districts). Melenky and Selivanovo districts were noted by single morbidity cases during the entire analyzed period (Fig. 3).

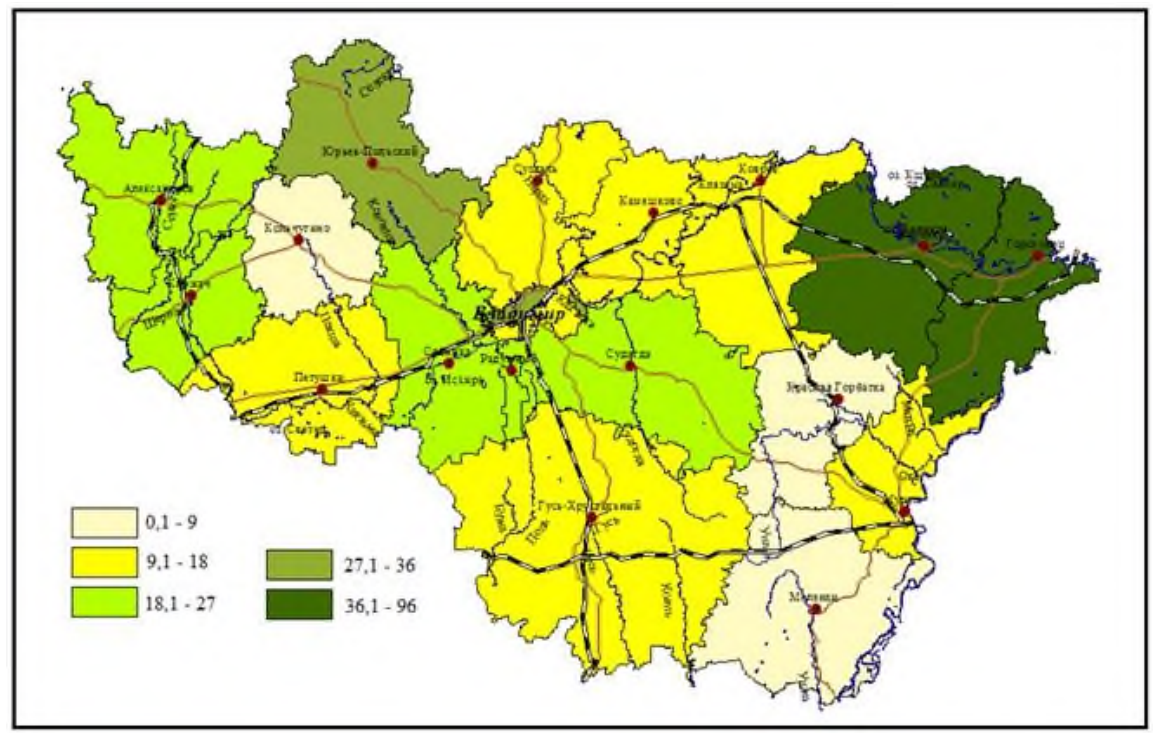

Fig. 3. Long term leptospirosis incidence in the Vladimir region (number of patients per 100,000 population).

During 2013 - 2015480 mouse-like rodents were studied in the Laboratory of Natural Focal and Especially Dangerous Infections using the reaction of microagglutination and leptospir lysis (RMAL), with the 3 positive results.

Holarctic subspecies of F. tularensis Subsp. holarctica, which demonstates significant resistance in the external environment, especially at low temperatures, is well preserved in water, withstands drying (it is preserved in the secretions of susceptible animals when completely dried and turned into dust) is tularemia pathogen on the territory of the Russian Federation. Spontaneous infection with tularemia pathogen has so far been detected among 145 animals, 82 - in Russia. Small mouse-like rodents, muskrats and hares have real epizootic value, however, when infected, they rarely live over 5-10 days, so each individual animal has an epizootic and epidemic value for a short period. The main reservoir providing tularemia pathogen circulation in nature is ixodic mites [9]. Pathogen can be preserved in their body for a long time. It is important to note that tularemia is observed only in the areas inhabited with ixodic mites. A person can become infected by ixodic mites attack, by water, food, air-dust, and contact. Human susceptibility to the pathogen is very high. Stable immunity is developed and allergization is noted in respect to the pathogen and its antigens after past infection. From 1958 to 2016, mostly single tularemia cases were registered in the Vladimir region (118 cases totally). In 2005 an outbreak was detected in the GusKhrustalny district: 28 cases were registered. It is interesting that in the same year in the neighboring Moscow region an epidemic tularemia outbreak was registered [10]. It is obvious that zero incidence of human tularemia for a number of years does not speak of the attenuation of the natural infection focus and the reason for seizing anti-tularemia measures. Besides it is worth noting that tularemia was not detected during this period in Kirzhach, Petushky, Selivanovo and Melenki districts (fig. 4). 


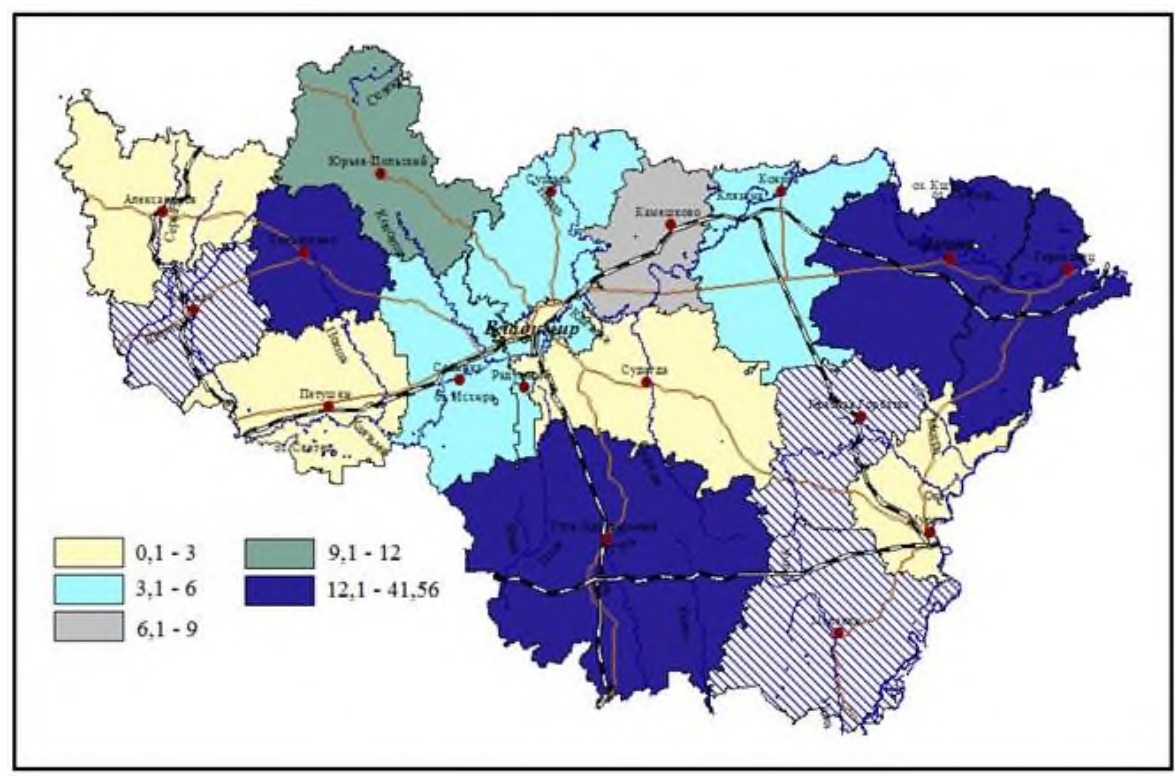

Fig. 4. Long term tularemia incidence in the Vladimir region (number of patients per 100,000 population).

During the period of 2013 - 2015, 417 rodents were studied using bioprobe method in the laboratory of natural focal and especially dangerous infections of FBUZ, but tularemia pathogen was not detected. About 1185 samples from environmental objects were examined, including 429 water samples, pathogen also was not detected. Serologically, 949 samples were examined from environmental objects, including bites of small mammals, burrow content, etc., positive result was obtained in 107 cases.

\section{Conclusion}

The retrospective analysis of statistical information allowed us to reveal that the Vladimir region area is endemic for a number of natural focal infections: HFRS, leptospirosis and tularemia, herewith HFRS is characterized by persistent natural foci.

The basic reasons, contributing to the natural focal infections circulation in the region, are the following:

- reduction of all types of deratization measures and, as a result, the increase of the mouse-like rodents population, which for some natural focal infections are the source (reservoir) of infectious agents (HFRS, leptospirosis, tularemia)

- insufficient population awareness of the preventive measures of natural focal infections.

Positive laboratory results indicate epizootic activity and constant risk of the epidemic situation exacerbation for anthropozoon infections, but zero human morbidity during a number of years does not indicate the attenuation of natural infection focus and the reason for seizing preventive measures. 


\section{References}

1. T.A. Trifonova, A.A. Martsev Natural-focal diseases in the vladimir region (Russia). Geography, Environment, Sustainability. 8(4). pp. 26-34 (2015) DOI: 10.24057/20719388-2015-8-4-26-34

2. T.A. Trifonova, A.A. Martsev Evaluation and prognosis of epidemiologic situation for lyme borreliosis in vladimir region. Zhurnal mikrobiologii, epidemiologii, $i$ immunobiologii. 1, 58-62 (2016)

3. A.A. Martsev, V.M. Rudakova, A.V. Ilina Epidemic and epizootic situation of naturalfocal zoonotic infections in vladimir region. Zhurnal mikrobiologii, epidemiologii, i immunobiologii. 5, 20-26 (2018) DOI: 10.36233/0372-9311-2018-5-20-26

4. A.A. Martsev, V.M. Rudakova Retrospective analysis of the epidemiological situation on parasitic diseases in the vladimir region. Gigiena i Sanitariya. 97(9), 825-830 (2018) DOI: 10.18821/0016-9900-2018-97-9-825-830

5. A.A. Zabnev, A.A. Golubkova, Ecological and epidemiological characteristics of an active focus of hemorrhagic fever with renal syndrome in the krasnoufimskiy district of sverdlovsk region. Infektsionnye Bolezni. 18(1). 23-28 (2020) DOI: 10.20953 / 17299225-2020-1-23-28

6. T.A. Savitskaya, V.A. Trifonov, Review of the current epidemiological situation on the incidence of hemorrhagic fever with renal syndrome in the world and forecast of the incidence for the territory of the Russian Federation in 2019. Problemy Osobo Opasnykh Infektsii. 2, 30-36 (2019) DOI: 10.21055/0370-1069-2019-2-30-36

7. S.M. Malkhazova, P.V. Pestina, V.S. Tikunov, Emerging and re-emerging natural focal diseases of european Russia (typological classification of nosological profiles and dynamics of incidence). Geography, Environment, Sustainability. 13(1), 115-127. DOI: 10.24057/2071-9388-2019-61

8. E.I. Andaev Results of immunological screening for natural-focal and "exotic" infectious diseases among certain population groups of the khabarovsk territory, the amur region and the jewish autonomous region. Problemy Osobo Opasnykh Infektsii. 1. 112-115 (2014)

9. I.S. Meshcheryakova, T.V. Mikhailova, The epizootic and epidemic activity of natural tularemia foci of different landscape epidemiological types in 2009-2014. Meditsinskaia parazitologiia i parazitarnye bolezni, 1, 42-46.

10. T.N. Demidova Epizootic and epidemic manifestation of natural foci of tularemia in moscow region (1965-2013). Zhurnal mikrobiologii, epidemiologii, i immunobiologii. (2), $24-62(2015)$ 